\title{
Correction to: Micellar electrokinetic chromatography as efficient alternative for the multiresidue determination of seven neonicotinoids and 6-chloronicotinic acid in environmental samples
}

\author{
Laura Carbonell-Rozas $^{1}$ • Francisco J. Lara ${ }^{1}$ - Monsalud del Olmo Iruela ${ }^{1} \cdot$ Ana M. García-Campaña ${ }^{1}$ (I)
}

Received: 10 September 2021 / Accepted: 10 September 2021 / Published online: 11 October 2021

(C) Springer-Verlag GmbH Germany, part of Springer Nature 2021

Correction to: Analytical and Bioanalytical Chemistry https://doi.org/10.1007/s00216-019-02233-y

The authors would like to call the reader's attention to the fact that, unfortunately, there was an error regarding Fig. 1 in this manuscript; please find the correct figure below.

\section{a}

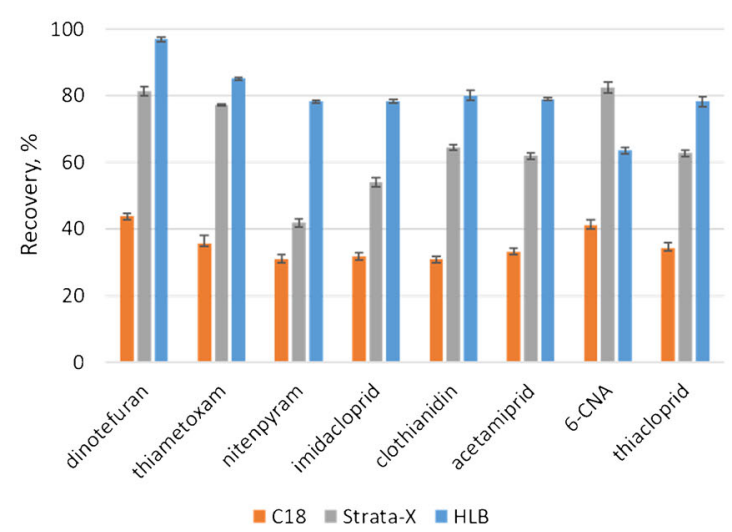

C18 $=$ Strata-X $=\mathrm{HLB}$

\section{b}

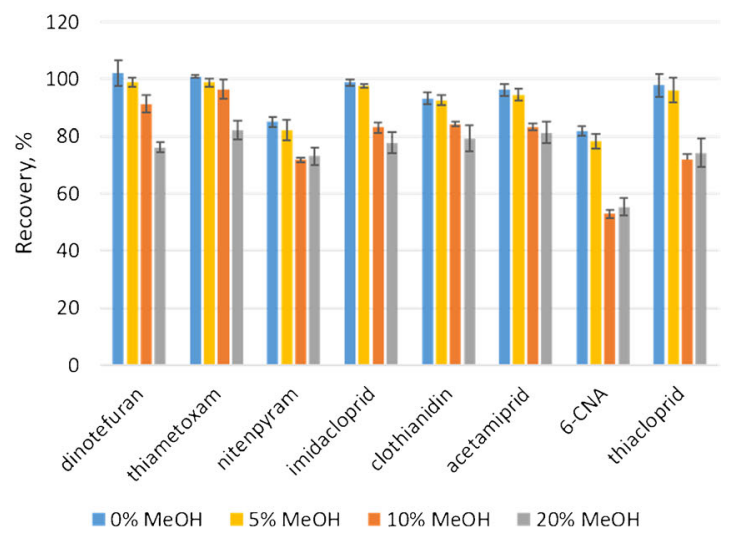

Publisher's note Springer Nature remains neutral with regard to jurisdictional claims in published maps and institutional affiliations.

Published in the topical collection featuring Female Role Models in Analytical Chemistry.

The online version of the original article can be found at https://oi.org/ 10.1007/s00216-019-02233-y

Ana M. García-Campaña

amgarcia@ugr.es

1 Department of Analytical Chemistry, Faculty of Sciences, University of Granada, Campus Fuentenueva s/n, 18071 Granada, Spain 